AUTOR: Adelina Millet.

UNIVERSIDAD: Instituto Universitario del Próximo Oriente Antiguo (IPOA), Universidad de Barcelona.

BREVE bIOGRAFÍA: Llicenciada en Filologia Semítica, àrea d'Estudis Hebreus i Arameus (I990); Master en Estudis Orientals a l'Institut del Pròxim Orient Antic de la Universitat de Barcelona (I993); doctora en Filologia Semítica per l'École Pratique des Hautes Études, París (200I). Professora al Departament de Filologia Semítica des de l'any 2000, impartint assignatures de llengua hebrea, accàdica, aramea i ugarítica, història d'Israel i Literatura de la Bíblia. Imparteix classes de llengua accàdia al Master d'Assiriologia de l'Institut del Pròxim Orient Antic. Ha publicat diversos articles en revistes especialitzades d'orientalística antiga; ha publicat també les traduccions, al català, del Poema Babilònic de la Greació i El Poema de Gilgamesh, així com l'edició, traducció i estudi dels textos cuneïformes del Jaciment de Chagar Bazar, a la República Àrab de Síria. És directora de la Missió Arqueològica de la Universitat de Barcelona a Tell Amarna, República Àrab de Síria.

TÍTULO: La geografia de la mort al poema de Gilgameš i al Pròxim Orient antic.

IITLE: The Geography of Death in the Gilgameš Poem and in the Ancient Near East.

RESUMEN: Sembla que els habitants del Pròxim Orient Antic, tant els sumeris com els accadis, i en general tots els pobles que parlaven llengües semítiques, tenien la creença que l'existència al més enllà seria una continuació de la vida a la terra, però en unes altres condicions, més extremes i dramàtiques. Aquest lloc es trobaria a sota de la terra on hi són els vius, això és, l'inframón o infern. L'inframón és imaginat com un lloc que es troba, doncs, sota terra i on hi viuen els déus infernals, alguns dimonis i els morts. Aquest lloc és imaginat com un espai grain, més aviat trist i hostil. Aquesta visió, que percebem a partir d'alguns textos literaris, és la que haurien tingut els habitants de Mesopotàmia i la zona de Síria fins al Mediterrani, des de l'època sumèria fins l'època neo-assíria i neo-babilònica.

ABSTRACT: It seems that the people of the Ancient Near East, both the Sumerians as the Akkadian, and in general all the speaking Semitic languages, held the belief that the existence beyond would be a continuation of life on earth, but in other conditions, more extreme and dramatic. This place would be found under the earth where the living are, that is, the underworld or hell. The underwold is imagined as a place that is therefore under land and where the infernal gods, some demons and the dead live. This place is imagined as a great space, sad and hostile. This vision, which we perceive from some literary texts, is what would have been the inhabitants of Mesopotamia and the area from Syria to the Mediterranean, from the Sumerian period to neo-Assyrian and neo-Babylonian period.

PALABRAS CLAVE: mort, inframón, arquitectura, espai literari.

KEYWORDS: death, underworld, architecture, literary space.

CONTACTO: amillet@ub.edu 



\section{LA GEOGRAFIA DE LA MORT AL POEMA DE GILGAMEŠ I AL PRÒXIM ORIENT ANTIC*}

Adelina Millet

\section{INTRODUCCIÓ}

La idea que es feien els antics habitants del Pròxim Orient Antic, ja siguin sumeris, accadis o els pobles semites occidentals, estava basada en l'observació de la realitat que els envoltava. Una terra més aviat plana, sense a penes accidents geogràfics; uns pocs rius, un pocs wadis que s'omplien d'aigua a l'estació de les pluges. Les muntanyes, per a penes inexistents, representen un espai desconegut i normalment lligat a forces sobrehumanes. A partir de la pura observació van adonar-se que els vius es trobaven a sobre de la superfície de la terra, els morts sota la superfície de la terra, ${ }^{\mathrm{I}}$ i els éssers divins, en principi, no s'haurien trobat a cap d'aquets dos llocs, sinó en algun lloc al cel. ${ }^{2}$ Les divinitats habitarien en els diversos nivells, o cels, que es troben sobre la superfície de la terra. ${ }^{3}$ Només algunes divinitats es trobarien al món dels morts, l'inframón, com ara alguns Anunnaku ${ }^{4}$ i la reina i el rei de l’inframón, Ereškigal i Nergal. ${ }^{5}$

Així doncs, el lloc on van a parar els humans després de morir es troba sota la terra on s'hi estan mentre estan vius, això és, l'inframón o món dels morts, que en accadi es diu igual que el lloc on es troben els vius, erșetu.

Hi ha diverses maneres d'accedir a l'inframón, és a dir, que hi ha diverses portes o accessos per entrar-hi. Un, el més evident, és a través de la tomba excavada a terra; un altre seria a través de la muntanya Mašu, que estava guardada per dos éssers sobrenaturals i monstruosos, els homes-escorpí. La imatge de les muntanyes, d'una certa alçada a més a més, com a llocs misteriosos i sobrenaturals es podria explicar per la particular geografia de la zona, on el territori és majoritàriament pla, almenys a la zona anomenada Mesopotàmia; les muntanyes representarien, llavors, llocs estranys i fins i tot perillosos. ${ }^{6}$ No és estrany, doncs, que una de les maneres d'accedir a l'inframón sigui a través d'una muntanya molt alta.

Un altre accés a l'inframón es trobaria més enllà del que al Poema de Gilgameš s'anomena "les aigües de la mort". ${ }^{7}$ Aquesta referència a les aigües de la mort, als confins de l'oceà, i que d'alguna manera serien l'accés al més enllà, només la trobem al Poema de Gilgameš.

\section{L'INFRAMÓN SEGONS ELS TEXTOS}

\section{I. Els noms de l'inframón}

Es coneixen diversos noms per designar les regions de la terra, una de les quals és l'inframón, tant en sumeri com en accadi. El més comú és l'accadi erșetu, que serveix per designar també l'inframón, i totes les parts de la terra, segons el text KAR 307

01. PLANTES D'ENTERRAMENTS DEL PERIODE DE YEMDET NASR (FINALS DEL IV MILENI), TROBADES PER SIR CHARLES LEONARD WOOLLEY A UR. MISSIÓ ARQUEOLÒGICA BRITÀNIC-NORD AMERICANA, PRINCIPIS DELS ANYS 30: ÚLTIMES TEMPORADES DE LA MISSIÓ DESPRÉS DE LA GRAN DEPRESSIÓ. PENN MUSEUM, FILADĖLFIA, EP-2012-2-1 (198703).
Aquest article ha estat realitzant gràcies a l'ajut del projecte FFI 2OI-25290 Edición y análisis del archivo oficial mesoasirio Asur M8, concedit pel Ministerio de Ciencia e Innovación.

I.

Vid. W. Horowitz, Mesopotamian Cosmic Geography, Winona Lake Indiana, I998, p. I8, I27-I28.

2.

Vid. W. Horowitz, Op. Cit., I998, p. I25-I27.

3 .

Vid. W. Horowitz, Op. Cit., I998, p. 8, 208 ss. i 223 ss.

4.

A l'Enuma eliš vi 39-44, però, es diu que són només la meitat dels Anunakku, 300, els que es troben a l'inframón.

5.

A la "terra mitja", suposadament en algún lloc entre la terra de dalt i l'inframón, hi habita el déu Ea, a l'Apsu, que seria una massa d'aigua, al mig de la qual, en un rai, s'hi trobaria el lloc on hi viu Ea, Vid. W. Horowitz, Mesopotamian Cosmic Geography, Winona Lake Indiana, I998, p. I7-I8.

6.

Vid. W. Horowitz, Op. Cit., I998, p. 98.

7.

Vid. Poema de Gilgameš, tauleta X 84, 86, IO2.

8.

Vid. W. Horowitz, Op. Cit., I998, p. I03-IO4. Encara que, després de creuar l'oceà i les aigües de la mort, Gilgameš el que pretén és arribar fins al lloc on habiten Utnapišti i la seva dona. És a dir, que no vol anar al lloc on hi viuen els morts, sinó més aviat al lloc on hi viuen els humans als quals les divinitats van concedir de no morir mai, una mena de paradís. 
Per a una explicació més detallada dels tres termes, vid. W. Horowitz, Mesopotamian Cosmic Geography, Winona Lake Indiana, I998, p. 274 ss.

IO.

La paraula sumèria uraš és una paraula que designa tant la terra com el cel, a W. Horowitz, Mesopotamian Cosmic Geography, Winona Lake Indiana, I998, p. 269 nota 2.

Vid. W. Horowitz, Mesopotamian Cosmic Geography, Winona Lake Indiana, I998, p. 27 Oss.
30-38, que són: la "terra de dalt", això és, la superfície de la terra on hi habiten els vius: erșetu elìtu; la "terra mitja”, on hi ha l'Apsu, la llar del déu Ea: erșetu qablītu; i la "terra de baix" o "inframón", on hi habiten els morts i algunes divinitats: erșetu šaplītu. ${ }^{9}$

Els diversos noms que designen la terra, tant el lloc dels vius com l'inframón, tant els més comuns com els més estranys, apareixen a les llistes lèxiques, que llisten paraules en sumeri, i les seves corresponents en accadi. En aquestes llistes hi trobem I7 noms en sumeri i 6 en accadi:

Sumeri
a.rá
arali
bùr
ganzer
idim
ki
kir ${ }_{5}$
kiši
kukku "Foscor"
kur
kur.gi
kunugi / kurnugia "La Terra sense retorn"??
lam / lamma
lamhuu
uraš ${ }^{10}$
urugal / erigal "Tomba / Gran Ciutat"
ZÉ

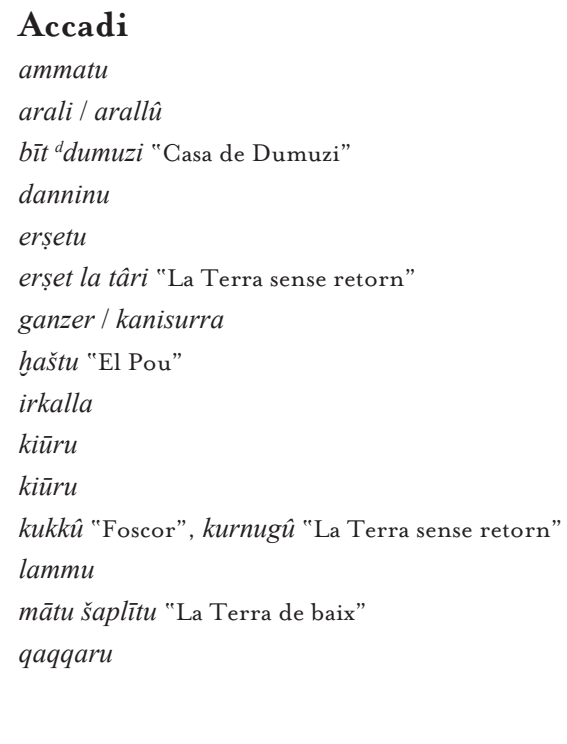

En algunes llistes hi trobem noms específics per indicar l'entrada a l'inframón, però que també indicarien l'inframón en el seu conjunt, per exemple, en sumeri: ḩilib / halib i ganzer. El primer, en la seva accepció restringida d'entrada a l'inframón es tradueix en accadi com pāni erșetim, "davant de l'inframón"; i el segon com bāb erșeti, "porta de l'inframón". ${ }^{11}$

Una de les designacions més interessants, i que troba ecos en altres geografies i en altres cronologies, és la designació de l'inframón com "La Terra sense retorn" (// el País d'aniràs i no tornaràs). Aquesta designació descriu a la perfecció quin és el destí dels humans que, amb una sola excepció, tots hi han d'anar. Aquesta excepció és la d'Utnapišti i la seva dona, els quals, després del diluvi enviat pels déus, van sobreviure i van ser fets immortals.

Les altres criatures que poden entrar i després sortir de l'inframón són dues, l'una ho pot fer lliurement, es tracta d'un personatge que pertany a la cort dels reis de l'inframón, el visir Kaka, que serveix de missatger. I el segon, que aconsegueix sortir només després d'haver-hi deixat algú altre per substituir-lo, és la deessa Inana / Ištar. Inana / Ištar vol conquerir el reialme de l'inframón i s'hi dirigeix per tal d'aconseguir-ho, hi entra, tot perdent tots els seus atributs, i finalment és morta i s'hi ha de quedar per sempre. Només en podrà sortir si troba algú que s'hi quedi en lloc seu, aquest serà el seu amant Dumuzi. 

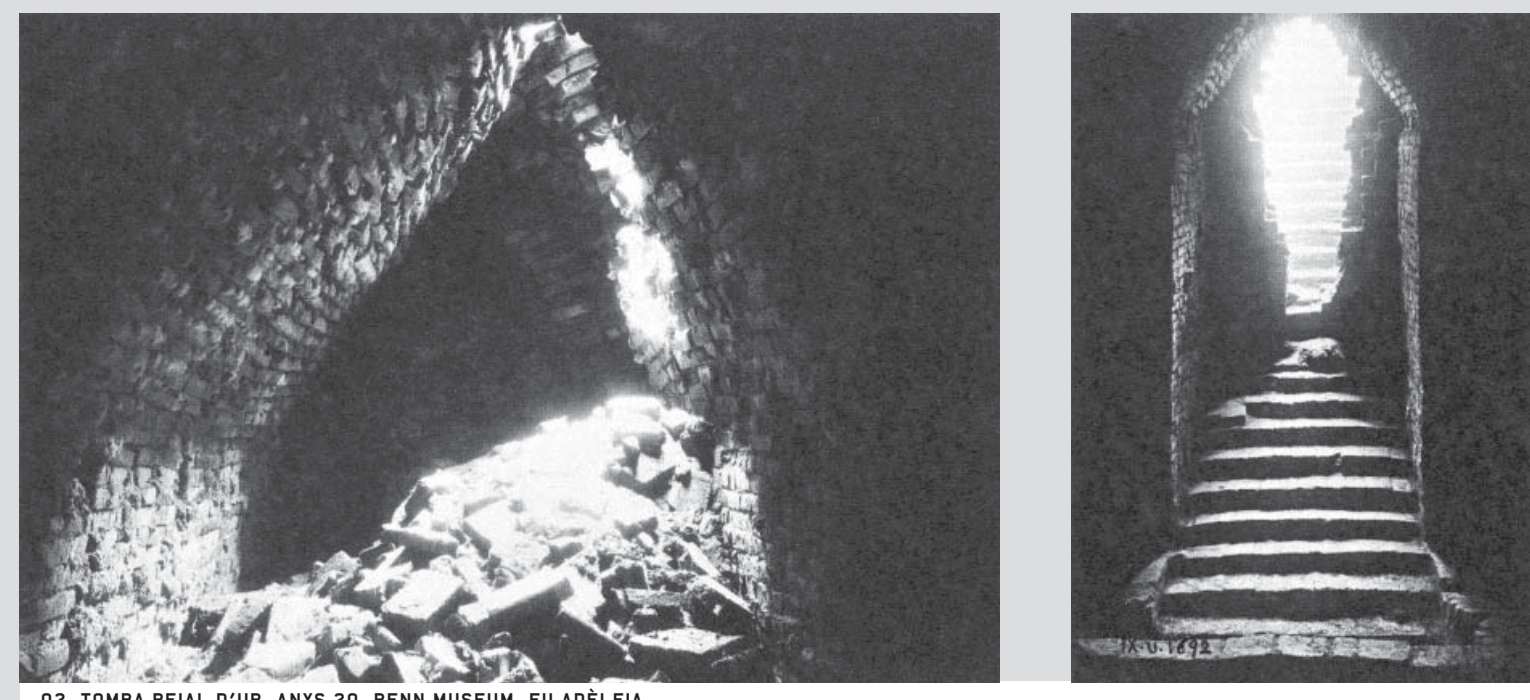

02. TOMBA REIAL D'UR, ANYS 20. PENN MUSEUM, FILADĖLFIA.

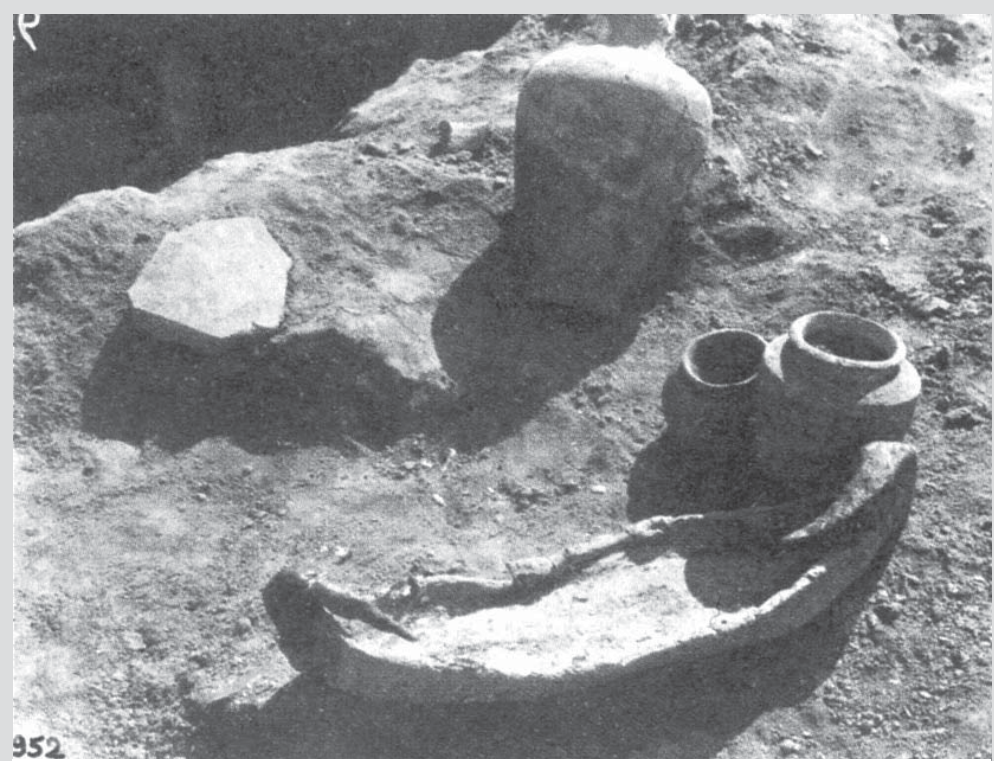

03. MODEL DE BARCA, POTSER D'ÚS FUNERARI, TROBADA A UR. MISSIÓ ARQUEOLÒGICA BRITÀNIC-NORDAMERICANA D'UR, DIRIGIDA PER SIR CHARLES LEONARD WOOLLEY, CA. 1925. PENN MUSEUM, FILADĖLFIA.

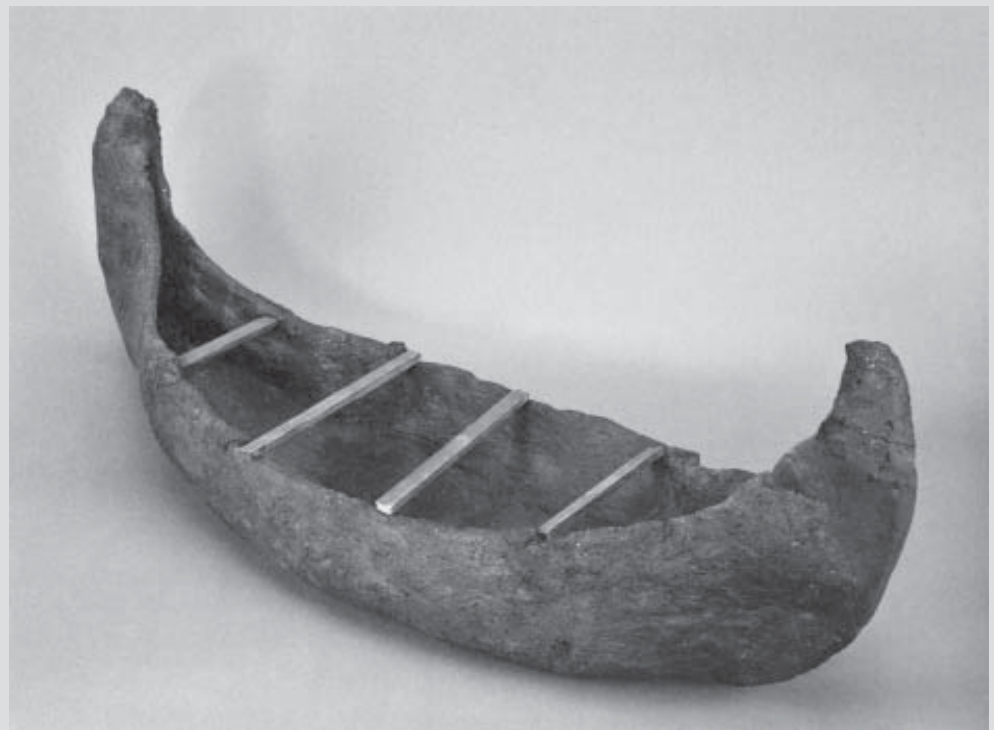

04. MAQUETA D'EMBARCACIÓ. UR (IRAK). PERÍODE ACADI ANTIC, 2334-2193 A.C. BITUMEN, FUSTA. 25,5X21X70 CM. BIRMINGHAM MUSEUMS AND ART GALLERY, 2006.0866. 
I2.

Vid. S. Anthonioz, "De la mort qui sépare à celle qui unit: le message et la formation de l'épopée de Gilgameš”, in J.-M. Durand-T. Römer-J. Hutzli (eds), Les vivants et leurs morts, OBO 257 , p. 83.

I3.

Vid. S. Anthonioz, "De la mort qui sépare à celle qui unit: le message et la formation de l'épopée de Gilgameš”, in J.-M. Durand-T. Römer-J. Hutzli (eds), Les vivants et leurs morts, OBO 257, p. 89.

$$
\text { I4. }
$$

La falta d'aigua i la set perpètua és una constant sobre la situació dels que habiten el món dels morts, i és molt important que els que s'hi trobin rebin aigua fresca. Vid. una maledicció que es troba a l'Epíleg del Codi de Hammurabi L 38-40 (XXVII 38-40) "Que la paraula dolenta de Šamaš que es compleixi de sobte: a dalt, que el faci fora d'entre els vius; a baix, a l'infern, que el seu fantasma (esperit, etemmu) tingui set d'aigua."

\section{I.2. Localització de l’Inframón segons el Poema de Gilgameš}

Com hem dit més amunt, segons ens expliquen alguns textos de la literatura del Pròxim orient Antic, hi ha diverses entrades a l'inframón. A la versió estàndard del Poema de Gilgameš se'ns explica com Enkidu baixa a l'inframón i com s'hi ha de quedar per sempre, a la tauleta xii. Aquesta versió en accadi és una mera traducció de part d'un relat en sumeri al voltant del rei Gilgameš, titulat Gilgameš i l'Inframón. En aquest relat, tant en llengua sumèria com en la seva traducció a l'accadi, està clara la idea que el món dels morts es troba sota terra i que per anar-hi cal "baixarhi”. En cap cas, però, està especificat quina és la manera concreta o el lloc exacte per on s'hi ha d'anar. També queda clar que és un lloc del qual és difícil tornarhi, de fet, si se segueixen unes instruccions minucioses, hauria estat possible per a Enkidu sortir-ne, però no les va tenir en compte i s'hi va haver de quedar.

\section{I.3. Geografia de l'Inframón segons el Poema de Gilgaměs}

Al relat sumeri Gilgameš i la mort, s'hi explica el plànol de la tomba de Gilgameš (1. $235-238)^{12}$, XXXX. La tomba serà immensa, i hi acollirà, no només el rei Gilgameš, sinó també les seves dones, els servents i els funcionaris reials. En cert sentit, es reprodueix al més enllà les circumstàncies de la vida quotidiana del rei.

Al mateix relat sumeri s'hi diu que el lloc de la tomba de Gilgameš no és conegut, o bé no es pot trobar. Hi trobem en aquest passatge un evident paral-lel amb un passatge ben conegut de la Bíblia, concretament Deuteronomi 34:5-6, on es relata la mort de Moisès i s'hi afegeix que el lloc on es troba la seva sepultura ningú no el coneix. ${ }^{\mathrm{I} 3}$

\section{I.4. La idea de l'inframón al Pròxim Orient Antic}

Segons hem vist més amunt, la idea que els sumeris i accadis tenien de l'inframón és bastant poc elaborada. Es tracta d'un lloc situat sota terra; es tracta d'un lloc fosc $\mathrm{i}$ on hi ha una permanent manca d'aigua i menjar, especialment d'aigua. ${ }^{\mathrm{I} 4}$ És un lloc del qual tothom en vol sortir però d'on només poquíssims han aconseguit fer-ho. És un lloc on no hi ha de res i on els qui s'hi troben depenen dels vius per sobreviure-hi.

Es conserven algunes descripcions de com és l'inframón, que trobem als textos literaris, en general el lloc no és agradable, encara que cada relat és particular.

Segons la visió d'un rei assiri en un malson, els qui es troben al món dels morts són condemnats a passar gana i set, i aquells que havien gaudit d'un alt status, com ara els reis, perdrien el seu status reial, i compartirien el destí d'aquells que han mort i no han tingut sepultura, ni ofrenes funeràries ni béns que els serveixin per viure millor a l'altre món.

Una altra descripció del món dels morts és la que fa Enkidu, el company de Gilgameš, però, aquesta seria menys terrible. Segons aquesta descripció, aquells que tenen més de dos fills mengen i beuen fins a saciar-se, estan contents i no els falta de res, ja que els seus descendents s'ocupen d'ells, de fer-los ofrenes al món dels vius per a que no els falti de res en el món dels morts. Mentre que aquells que només tenen un fill, o cap, no tenen res per a menjar ni per a beure, i s'han de conformar amb el que els sobra als altres, o amb el fang dels carrers:

["Oh!",] exclamà [el senyor] caient [a] la pols. XII 100

["Oh!",] exclamà [Gilgamesh] caient [a la po]ls.

["Has vist el qui té un fill?"] "L'he vist".

"Plora [amargament] davant d'un [cl]au clavat a la paret". 


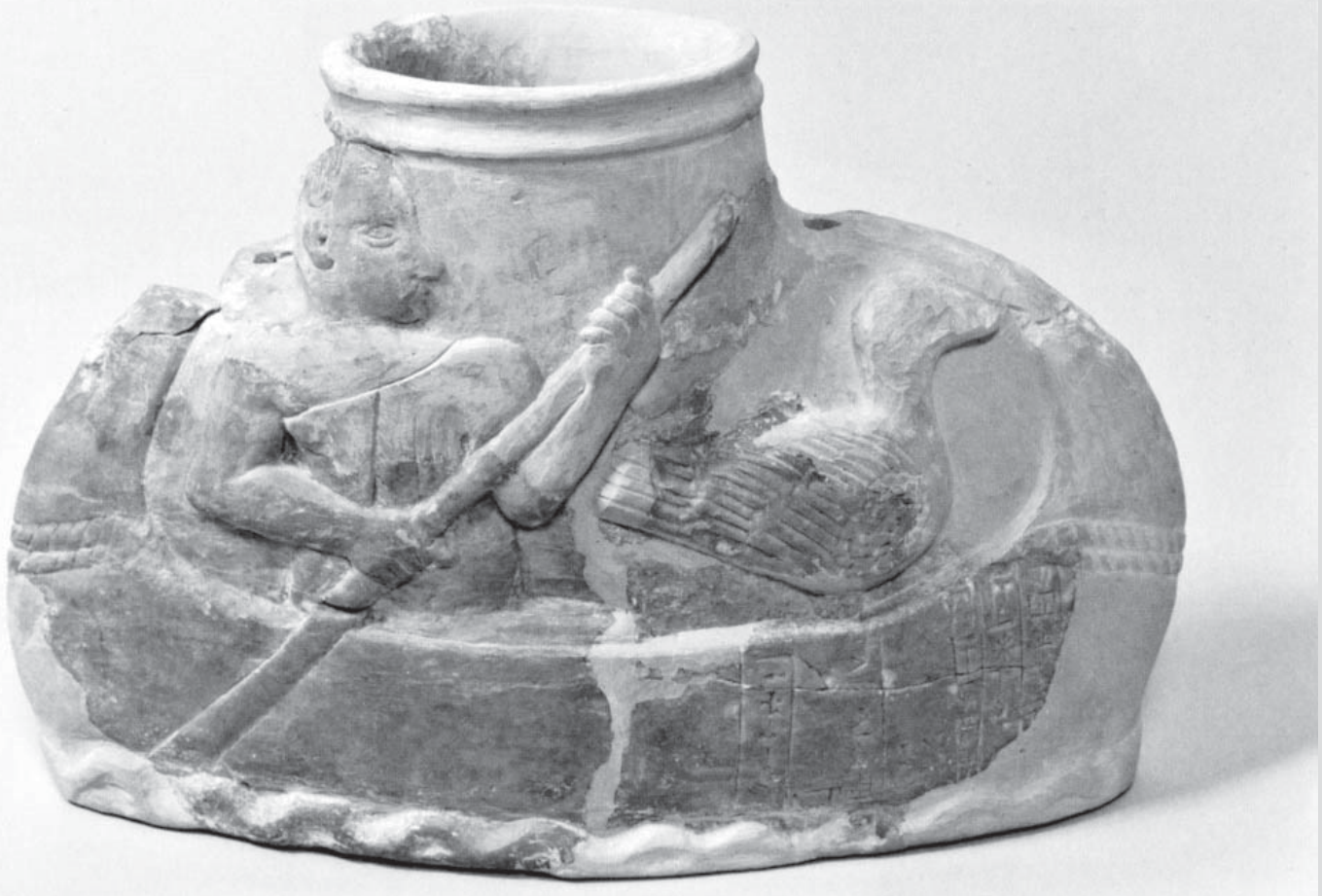

05. VAS VOTIU EN FORMA D'EMBARCACIÓ. TAMPLE, MONTÍCUL V, BISMAYA (L'ANTIGA ADAB, IRAK). PERÍOdE TERCERA DINASTIA D'UR, $2112-2004$ A.C. 14,5 X 22,5 X 8,3 CM. ORIENTAL INSTITUTE MUSEUM, CHICAGO, A236.

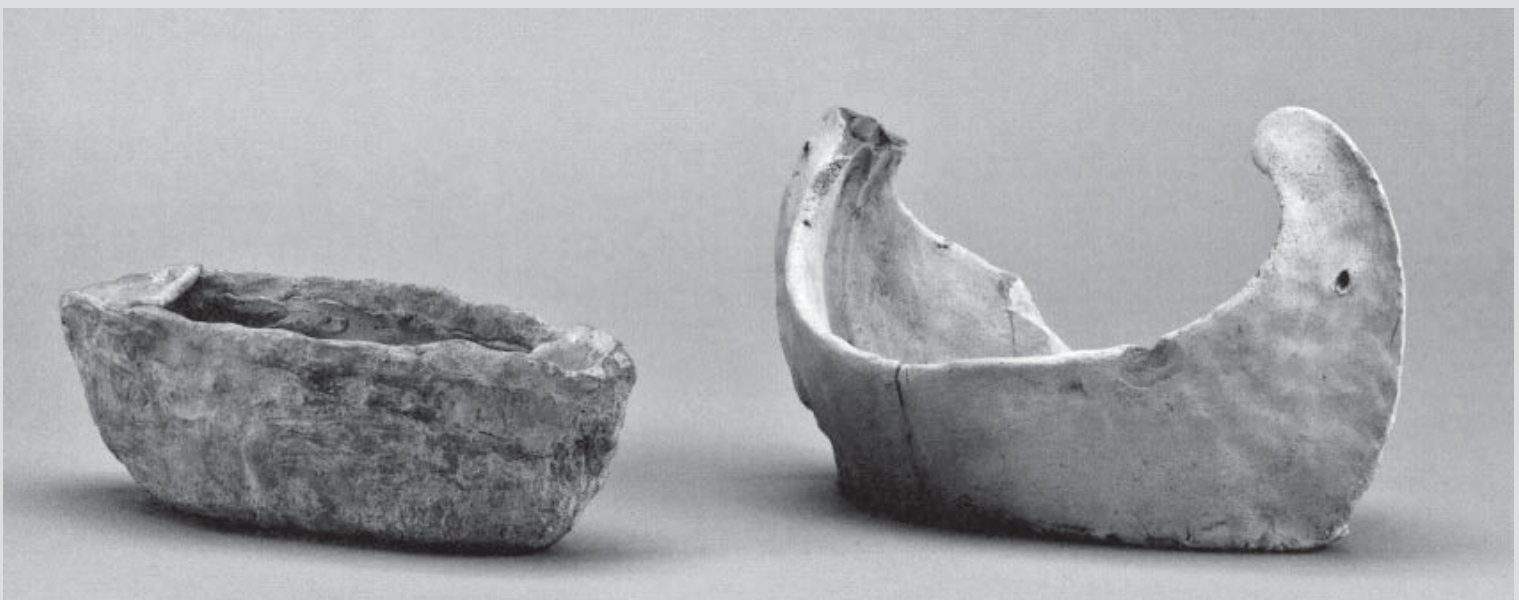

06. MAQUETES D'EMBARCACIONS. ESQUERRA: UR (IRAK). PERÍODE BABILÒNIC ANTIC, 2000-1600 A.C. TERRACOTA, 19,6 X 7,5 X 6,5 CM. EXPEDICIÓ CONJUNTA A UR, 1930-1931. PENN MUSEUM, FILADËFIA 31-43-358. DRETA: FARA (IRAK), NIVELL III, FG 43, TOMBA DE CISTA. UR III, 21122004 A.C. TERRACOTA. 11, 5 X 21,6 X 11,3 CM. EXPEDICIÓ A FARA, 1931. PENN MUSEUM, FILADËFIA, 33-13-607.

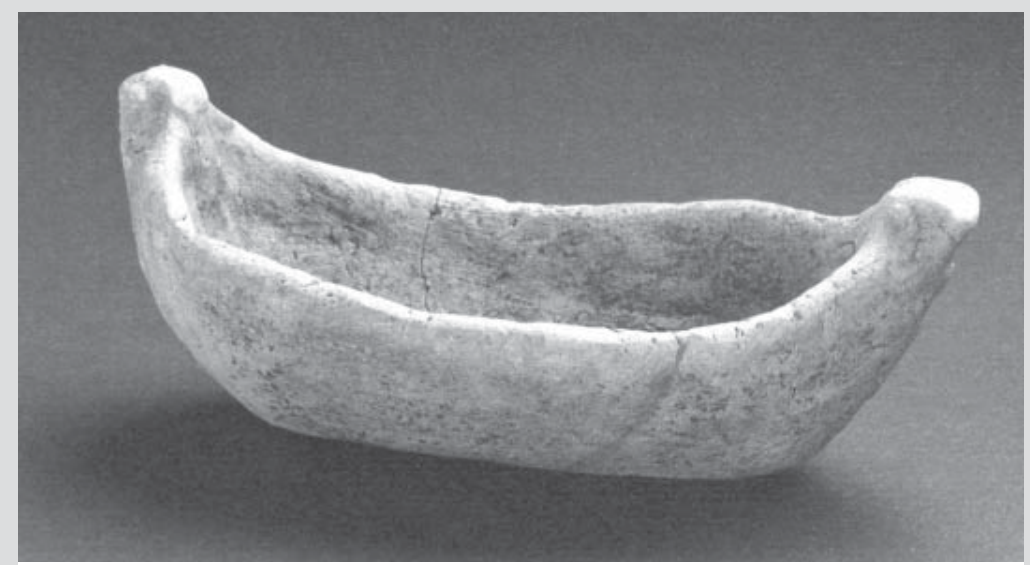

07. MAQUETA D'EMBARCACIÓ. YEMDET NASR (IRAK). PERÍODE DE YEMDET NASR, CA. 31002900 A.C. ARGILA. 15 X 8,8 8 7,7 CM. VISITORS OF THE ASHMOLEAN MUSEUM, OXFORD, AN 1926.478 
["Has vist el qui té dos fills?"] "L'he vist".

["Viu entre dos maons] (i) menja pa".

XII 105

["Has vist el qui té tres fills?"] "L'he vist".

"Beu aigua [d'una bóta penjada a la sella.]"

["Has vist el qui té quatre fills?"] "L'he vist".

El seu cor estava alegre [com (el propietari) d'un tir d'[ases].

"Has vist [el qui té cinc fills?"] "L'he vist".

El seu braç estava preparat [com] un bon [escriba],

va entrar directament al palau".

I5.

Vid el Poema de Gilgameš xii Iooss.

I6.

Descens d'Ištar a l'Inframón I-II. Una altra versió molt semblant la trobem en una versió més antiga de l'inici del mite, es troba en una tauleta escolar en la qual hi ha escrit un himne a Tiglatpilesser I (IOI4-IO76) i al final de la tauleta, hi trobem les II primeres línies del Descens d'Iśtar a l'Inframón, que fa així:

A la deessa, La Senyora de la Gran Terra,

a la deessa que viu dins l'Irkalla, el territori de Gingal, La Senyora de la Gran Terra,

a la deessa que viu dins l'Irkalla, la casa de l'Irkalla, (allà on) els que hi van no en tornen,

el lloc on la llum no arriba a la seva gent,

el lloc on els morts estan coberts de pols,

la casa de la foscor, (on) les estrelles no aparèixen.

La filla de Sin va parar atenció, va parar atenció $i$ orelles, (allà on) els que hi van no en tornen.

Gairebé la mateixa descripció la trobem al Poema de Gilgameš vii I82-I92:

"[Em va peg]ar, em va convertir en un colom,

[va lli]gar els meus braços com (les ales) d'un ocell,

em va capturar i em va conduir

a la casa de la foscor, la llar

d'Irka $\bullet$ a,

a la casa de la qual qui hi entra ja no en surt,

al camí que no té viatge de tornada, a la casa on els habitants de la qual estan privats de llum, allà on el seu aliment és la pols i el seu menjar és el fang,

vestits com ocells, guarnits amb ales,

no veuen la llum, viuen entre tenebres.

Sobre la por [ta i el pany s'hi acumula la pols, ]

sobre la ca Lsa hi plana un silenci mortal.]"
"Has vist [el qui té sis fills?"] "L’he vist".

["El seu cos estava content com el d'un pagès".]

"Has vist [el qui té set fills?"] "L'he vist".

["S'asseu en un tron a l'assemblea dels déus joves". ]15

La vida al món dels morts és, doncs, un calc de la vida a la terra. Els elements que en aquesta vida juguen el principal paper per a la subsistència del cos, la descendència que fa poderoses les famílies, i que permet als vells sobreviure quan ja han perdut les forces per procurar-se aliment, casa, vestits, etc., és el que també ha de passar, necessàriament, a l'altra vida. Els morts dependran per sempre més de la fidelitat dels que es queden, i dels que vindran, per poder-se mantenir en el món dels morts. Encara que els morts poden influenciar els vius, els morts no poden fer res per ajudar-se a ells mateixos, en això sempre dependran dels vius.

Tenim encara una tercera descripció de com seria el món dels morts, el trobem en un text literari El descens d'Ištar a l'Inframón, que es conserva en sumeri i en accadi, aquesta segona bastant més breu. La descripció no és gaire diferent de les que ja hem esmentat:
A l'Infern, el país sense retorn,
Iśtar, la filla de Sin, va parar orelles.
Realment, la filla de Sin, va parar orelles,
vers la casa obscura, la llar d'Irkalla,
vers la casa de la qual qui hi entra no en surt,
vers el camí que no té viatge de tornada,
vers la casa que la seva entrada està privada de llum,
allà on l'aliment és la pols (i) el menjar és el fang.
No veuen la llum, viuen entre tenebres,
vestits com ocells, guarnits amb ales,
sobre la porta i el forrellat s'hi acumula la pols. ${ }^{16}$

Des d'un punt de vista espacial, la idea que es tenia de l'inframón és com un calc del món dels vius, com acabem de dir més amunt. Sabem, a partir de les llistes lèxiques, que aquest lloc era imaginat com una ciutat molt gran, recordem el terme sumeri e rigal "Gran Ciutat". És un lloc gran, i és un lloc fosc, malgrat que rep la visita de Šamaš, el Sol, que també pot fer arribar una mica d'aigua fresca als que viuen al món subterrani, però sense poder canviar massa les condicions de vida dels que s'hi troben. La lluna també visitava l'inframón una vegada al mes, els dies en què no és visible per als vius. Moltes de les característiques de l'inframón que trobem descrites en els textos són més aviat arquitectòniques que no pas topogràfiques.

Potser arran de la idea de Gran ciutat que és el que significa el mot sumeri esmentat, algunes de les descripcions i referències que trobem en alguns textos ens descriuen alguns elements característics de les grans ciutats mesopotàmiques. $\mathrm{Al}$ text conegut com La mort d'Ur-Nammu, aquest rei visita els palaus dels déus infernals Nergal, Gilgameš, Ereškigal, Dumuzi, Hušbiša, Ningišzida, entre altres, i els porta regals, abans que ell hi tingui el seu propi palau al món dels morts. 
Al Descens d'Ištar a l'Inframón es diu que els Anunnakū viuen en un palau; i segons un text funerari provinent d'Elam, aquests viurien en un temple amb una torre. ${ }^{17}$

En un text provinent de Sultatepe, Nergal i Ereškigal, la reina de l'inframón rep la seva cort al pati del seu palau; en una versió provinent d'Amarna, els rep al seu temple. La presència de palaus, patis, temples i fins i tot torres, fa pensar que que els habitants d'aquesta zona concebien el més enllà com un gran complex amb diversos temples i palaus. Potser el comú dels mortals no s'imaginava pas que hi viuria, una vegada mort, però segurament sí seria el cas d'alguns reis, com hem vist més amunt.

\section{I.5. Situació i descripció de l’Inframón}

L'inframón, com hem dit més amunt, és la part més baixa de l'univers, la llar de les dues divinitats que hi regnaven, Ereškigal i Nergal i dels Anunnakū, i el darrer lloc on anaven a parar els humans després de morts, i es trobava localitzat sota la terra on es trobaven els vius i sota l'Apsu.

\section{I.5.I. La creació de l'Inframón ${ }^{\mathrm{I} 8}$}

No hi ha gaire informació sobre els orígens de l'Inframón. Sembla, de fet, que hi ha només una referència a la construcció de l'Inframón que es troba en un passatge molt curt d'un text sumeri titulat Lugale, on s'explica com el déu Ninurta construeix urugal amb pedra. Aquí urugal vindria a significar inframón i no només tomba. Segons aquest text, l'inframón s'hauria construït amb el cos de pedra del dimoni asakku.

Un altre text parla també de l'inframón en els seus orígens, però no referit a la seva creació. El text sumeri Gilgameš i l'inframón explica que, al principi dels temps, els déus es reparteixen les regions del cosmos, la deessa Ereškigal rep l'inframón (k u r ) com a regal del seu pare Enlil, després que Anu hagi agafat el cel (a n) i el mateix Enlil la terra (ki ) com a propietat de cada un. Els estudiosos diuen que a partir d'aquest text sembla que l'inframón és una part de la terra.

\section{I.5.2. La geografia de l'Inframón}

A pesar de que en tota la literatura en cuneiforme hi ha moltes referències a l'inframón, i es coneixenen diverses maneres d'anomenar-lo, no es coneix quina era la seva geografia interior, a banda de les que hem indicat més amunt (I.4.) La major part de la informació ens explica com accedir a l'inframón, més que no pas com és aquest lloc.

\section{I.5.2.I. Aspectes topogràfics}

Les poques evidències topogràfiques sobre l'inframón les trobem en un passatge del text sumeri Damu a l'Inframón. Es diu que les coses de l'inframón són molt diferents del món dels vius, però s'explica que hi ha rius, camps i ramats de xais. Es diu que els rius de l'inframón no porten aigua, als camps no hi creix el gra i els xais no produeixen llana. ${ }^{19}$

\section{I.5.2.2. Com s'arriba a l'Inframón i com s'hi entra}

La descripció més comuna de la ruta per arribar a l'Inframón parla que s'ha de seguir un camí que va des de la superfície de la terra fins a un riu que flueix cap a l'entrada de l'inframón. Tots els humans han de passar per aquest camí en direcció de la mort.
I7.

Vid. W. Horowitz, Mesopotamian Cosmic Geography, Winona Lake Indiana, I998, p. 350 .

I8.

Vid. W. Horowitz, Mesopotamian Cosmic Geography, Winona Lake Indiana, I998, p. 348-349.

I9.

UET 6/I 23 rev. 26-28. 
20.

Vid. W. Horowitz,

Mesopotamian Cosmic Geography, Winona Lake Indiana, I998, p. 355 .

$2 \mathrm{I}$.

SAA 3 7I no. 32 rev. 5 .

22.

Vid. W.R. Sladek, Inanna's Descent to the Netheworld, II 8: II9-I2O.

23.

Vid. W. Horowitz,

Mesopotamian Cosmic Geography, Winona Lake Indiana, I998, p. 358.

24.

Vid. Nergal i Ereškigal en les seves diverses versions, a W. Horowitz, Mesopotamian Cosmic Geography, Winona Lake Indiana, I998, p. 358 i n. 52 .

25.

Fora del món intangible, trobem un exemple de la doble presència de porters per vigilar una sola porta, es tracta de l'accés a l'interior de la part privada del palau de Mari, on és evident que hi ha un grup de porters que vigilen la porta per la part de dins, i un grup de porters que la vigilen per la part de fora, vid. N. Ziegler, Le harem de Zimri-Lim, Florilegium Marianum IV, p. IIO i II3.

26.

Vid. W. Horowitz, Mesopotamian Cosmic Geography, Winona Lake Indiana, I998, p. 359, on es detallen els elements que formen una porta com aquesta.
Els déus, els dimonis i altres éssers sobrenaturals tenen rutes alternatives per arribar-hi, ells poden accedir-hi directament des del cel per "l'escala del cel", que els porta des de les portes del cel fins a les portes de l'infern, com s'explica al text Nergal i Ereškigal, o bé per certes escletxes que hi hauria a la superfície terrestre, com és el cas d'Enkidu a Gilgamešil'inframón, on el seu esperit surt de l'inframón d'aquesta manera.

\section{El camí}

El camí que porta a l'inframón apareix citat en diversos textos literaris, però no en fan cap descripció, i el final del camí varia. En algunes ocasions, el camí acaba directament a l'inframón, i d'altres acaba en un riu, que després s'ha de creuar per arribar-hi.

L'únic itinerari cap a l'inframón el trobem al Descens d'Ǐtar a l'Inframón. S'explica com surt des de la seva ciutat, Uruk i, resseguint la vora del canal Iturungal, passa les ciutats de Bad-Tibira, Zabalam i Adab, després va cap al nord fins a Nippur, Kiš i, finalment, Akkad. Des d'allà accedeix directament a l'inframón. ${ }^{20}$

\section{El riu}

Un bon nombre de textos, tant sumeris com accadis, parlen d'un riu que flueix a la l'entrada de l'inframón. En els textos sumeris, el riu no està identificat amb cap nom, segons els textos accadis el riu porta el nom de Hubur. Es podria deduir que els que han d'entrar a l'inframón ho podrien fer a sobre d'una barca, igual que Caront a la mitologia clàssica. I, de fet, en algun text apareix aquest barquer, anomenat Humuțtabal. ${ }^{21}$

Hi troben una certa contradicció entre el fet de l'existència d'aquest riu, el qual, segons alguns textos fluiria per dins de l'inframón, i totes aquelles referències, ja esmentades, a la manca d'aigua fresca que, de forma permanent, pateixen els que es troben a l'inframón.

\section{Les portes}

L'aspecte més ben conegut de l'inframón són les seves portes, aquestes porten condueixen des de l'entrada externa de l'inframón, fins a l'interior més profund. A partir de nombrosos textos sabem que el total de portes que s'han de franquejar són set. L'explicació més detallada de cada una de les portes la trobem al text Descens d'Ištar a l'Inframón. En el text en sumeri hi trobem les instruccions que la reina Ereškigal dóna al porter, Bidu, de com ha de ser la recepció de la seva germana, la deessa Ištar:

II9. Que els panys de la porta de l'inframón, totes set, siguin tancats. 120. Que les portes de del palau de l'Inframón s'obrin una a una. ${ }^{22}$

A partir de la interpretació d'aquest passatge, les set portes estarien localitzades, totes, al palau, és a dir, en un únic complex arquitectònic, més que no pas set portes en set complexos diferents, en set murs concèntrics, o bé set portes disperses per l'inframón. ${ }^{23}$

Altres exemples ens presenten les set portes amb els seus respectius porters. ${ }^{24} \mathrm{~A}$ la versió de Nergal i Ereškigal trobada a Amarna, apareixen els noms de I4 porters, cosa que fa dues persones per cada porta. ${ }^{25}$ I pel que fa a la seva forma, sembla que les portes d'accés a l'Inframón serien idèntiques a les portes que donaven accés a les ciutats al món dels vius, sobre la superfície de la terra. ${ }^{26}$ 
Hi ha dos textos que es refereixen a escales que donarien accés a l'inframón. La simmilat šămamī es tradueix com "l'escala del cel" i uneix directament la porta dels déus Anu, Enlil i Ea, que es troba al cel, amb la porta d'Ereškigal, a l'entrada de l'inframón, passant a través de la superfície de la terra, de l'Apsu i del riu Hubur, que s'hi troben entremig. ${ }^{27}$

\section{Escletxes}

Els éssers demoníacs i els fantasmes solen passar per les escletxes que es troben a la superfície de la terra, i que donen accés directe a l'inframón. En aquest cas, no cal utilitzar les portes d'accés a l'inframón. És així com el fantasma d'Enkidu en surt, per parlar amb Gilgameš. ${ }^{28}$

Aquestes obertures a la superfície de la terra, que servirien de comunicació entre el món dels vius i el món dels morts, es poden comparar amb les conduccions de ceràmica, com petites canalitzacions, que es col-locaven a terra i que servien de conductes per les libacions ofertes als morts. ${ }^{29}$

\section{Muntanyes}

Sembla que podria haver estat possible accedir també a l'inframón creuant "muntanyes distants". El déu principal de l'inframón, Nergal, s'associa amb la muntanya per on surt el sol. $3^{30}$

\section{I.5.2.3. Mida i forma de l'Inframón}

A partir dels noms que se li dona a l'inframón es pot deduir que el lloc havia de ser molt gran, però en cap cas s'especifiquen unes mesures concretes. De l'inframón es diu, doncs, que és "gran", kur.gal, kur.dagal, ki.gal, ki.dagal, u r u ga l, ki gall u, erșetu rabitu, erșetu rapaštu. On veiem que el mot sumeri g a l té el significat bàsic de "gran", així com el mot accadi rabû. També es qualifica l'inframón d'"ample", en accadi rapšu.

En una ocasió es parla del "cercle de l'inframón", cosa que faria pensar que s'entenia que l'inframón tindria una forma circular, igual que el cel i la superfície de la terra. ${ }^{3 \mathrm{I}}$

\section{L'INFRAMÓN SEGONS LES DADES ARQUEOLÒGIQUES}

\section{I. Introducció}

En termes generals, i a falta d'exemples que demostrin el contrari, podem dir que al Pròxim Orient Antic els morts únicament s'enterren. Sabem que el fet de no enterrar-los provoca greus distorsions, els morts, en forma d'esperits, turmenten els vius. Per tant, sembla que no hi ha túmuls, ni cremació, ni altres pràctiques que no sigui l'enterrament, almenys no de forma significativa. S'enterra els morts sota terra, ja sigui en tombes directament al terra, o bé en cavitats amb diverses inhumacions.

De tota manera, hi ha opinions que diuen que, finalment, sembla que la destrucció de tombes tampoc no feia tant de respecte entre els vius, com en un principi ens podríem imaginar (amenaces, creences, etc.), si tenim en compte que, repetidament, noves construccions podien destruir tombes més antigues (p. I77). ${ }^{32}$
27.

Nergal i Ereškigal, vid. també W. Horowitz, Mesopotamian Cosmic Geography, Winona Lake Indiana, I998, p. 359s.

28.

Poema de Gilgameš xii 8I-86.

29.

Vid. W. Horowitz, Mesopotamian Cosmic Geography, Winona Lake Indiana, I998, p. 36I.

30.

Vid. W. Horowitz, Mesopotamian Cosmic Geography, Winona Lake Indiana, I998, p. 36I.

3I.

Vid. W. Horowitz, Mesopotamian Cosmic Geography, Winona Lake Indiana, I998, p. 36I.

32.

Vid. J.-F. Salles, "Rituel Mortuaire et Rituel Social à Ras Shamra / Ougarit", in S. Campbell-A. Green (eds) The Archaeology of Death in the ANE, Oxbow Monograph 5I, I995, p. I77. 
33.

En un context més precís, J.-F. Salles, "Rituel

Mortuaire et Rituel Social à Ras Shamra / Ougarit", in S. Campbell-A. Green (eds) The Archaeology of Death in the ANE, Oxbow Monograph 5I, I995, p. I84, es fa la pregunta de quina diferència hi hauria entre els morts enterrats a sota de les cases i aquells que van ser enterrats en un lloc fora del lloc d'habitatge. L'autor es posa la pregunta però no la respon.

\section{4 .}

Vid. D. Ilan, "Mortuary Practices at Tel Dan in the Middle Bronze Age: a Reflection of Canaanaite Society and Ideology”, in S. Campbell-A. Green (eds) The Archaeology of Death in the ANE, Oxbow Monograph 5I, I995, p. I2 I-I35.

\section{5 .}

Vid. E. Baxevani, "The Complex Nomads: Death and Social Stratification in EB IV Southern Levant", in S. Campbell-A. Green (eds) The Archaeology of Death in the ANE, Oxbow Monograph 5I, I995, p. 9I.

\section{6 .}

Vid. J.-F. Salles, "Rituel Mortuaire et Rituel Social à Ras Shamra / Ougarit", in S. Campbell-A. Green (eds) The Archaeology of Death in the ANE, Oxbow Monograph 5I, I995, p. I73-I76.

\section{7.}

Vid. H. Baker, "NeoBabylonian Burials Revisited", in S.

Gampbell-A. Green (eds) The Archaeology of Death in the ANE, Oxbow Monograph 5I, I995, p. 2I8-2I9.

\section{8.}

Vid. E. Baxevani, "The Complex Nomads: Death and Social Stratification in EB IV Southern Levant”, in S. Campbell-A. Green (eds) The Archaeology of Death in the ANE, Oxbow Monograph 5I, I995, p. 92 i IO9.
Les dades arqueològiques del IV milen·ni a.C. (periode d'Uruk ca. 4000-3100 a.C.) pel que fa als enterraments, són inexistents. S'ha suggerit que potser els enterraments haurien tingut lloc a fora dels assentaments humans, o bé que les pràctiques funeràries eren tals que no van deixar cap traça arqueològica. Durant el periode Dinàstic Antic (2900-2373 a.C.) es tenen moltes més dades, i es troben enterraments que tenen lloc tant en cementiris (a fora dels assentaments humans) com a sota de les cases. ${ }^{33}$

Per exemple, a Tell Dan (Bronze Mig) totes les tombes excavades es troben sota les cases, la casa i les tombes que contenen estaven sens dubte associades a la mateixa família. Es planteja la possible creença en la vida al més enllà o un renaixement, a causa de la posició fetal dels cossos dipositats a les tombes, amb el cap normalment orientat cap a la sortida de la tomba, o cap a la boca de la gerra (com l'orientació del nadó a l'úter matern al moment de néixer). Segons aquesta teoria, la construcció de les tombes a Tell Dan indicaria una còpia dels òrgans femenins al moment del naixement. ${ }^{34}$ En general, sembla que la disposició dels cossos enterrats és amb el cap en direcció nord. 35

A Ugarit també trobem majoritàriament les tombes a sota les cases, però no sempre, també hi ha exemples de cases sense tombes a sota, per tant, no es pot establir com a regla: I casa = I tomba. Potser hi ha tombes on s'enterrarien diversos membres d'un clan, o una família estesa; és potser per això que hi hauria cases sense tomba a sota. A més a més, sembla que, a Ugarit, les tombes sota les cases es construeixen al mateix temps que les cases, o bé es poden afegir després; s'hi té accés des de dins de la cas, i també des del carrer. ${ }^{36}$

En època neo-babilònica els enterraments es localitzen tant intra- com extramurs dels llocs d'habitatge. Quan els enterraments eren intra-murs es pot observar en moltes ocasions que aquestes inhumacions estaven concentrades en una habitació de la casa. ${ }^{37}$ En alguna ocasió, a sota d'aquesta habitació principal s'hi construiria la cambra funerària, aquesta habitació era normalment la cambra més important de l'habitatge, on es rebien les visites, sembla que a l'inframón es reproduiria aquesta cambra i les seves funcions.

La reflexió que s'imposa respecte dels morts i del lloc on aquests reposen, podem dir que, encara eu la mort és un afer diví, en el sentit que els déus van imposar la mort com a destí dels humans, els morts mateixos no són un afer diví, sinó un afer de les persones vives. Els morts pertanyen als vius i no a les divinitats, i són els vius que assumeixen les responsabilitats que comporta el fet de viure en societat. $\mathrm{O}$, dit d'una altra manera, cada grup humà és responsable, no només dels vius, sinó també dels seus morts, gairebé en la mateixa mesura que ho són els vius.

\subsection{La preparació del cos}

Les evidències arqueològiques dels esquelets excavats a les tombes semblen demostrar que, al moment de la mort, els cossos es preparaven d'alguna manera per al funeral (periode Dinàstic Antic), però sense que poguem establir de quina manera es faria això exactament.

Al costat dels cossos s'han trobat objectes de diversos tipus, com ara agulles i altres peces de joieria, petits recipients amb cosmètics, segells, etc. Estaríem al davant de tombes on la persona enterrada era una dona. Les tombes on hi hauria homes inhumats contindrien armes o eines i estris associats a una professió ; de fet, algunes tombes amb inhumacions d'homes, contenen dagues, punyals, etc., bé com a símbol del sexe del mort, o bé pel seu ús al més enllà. ${ }^{38}$

Després de ser rentat i ungit (suposadament), el cos es vestia, pel que es desprèn de les restes trobades a les tombes, on no s'hi troben restes de vestit, però sí agulles i altres estris que haurien servit per aguantar els vestits. S'ha de descartar completament 


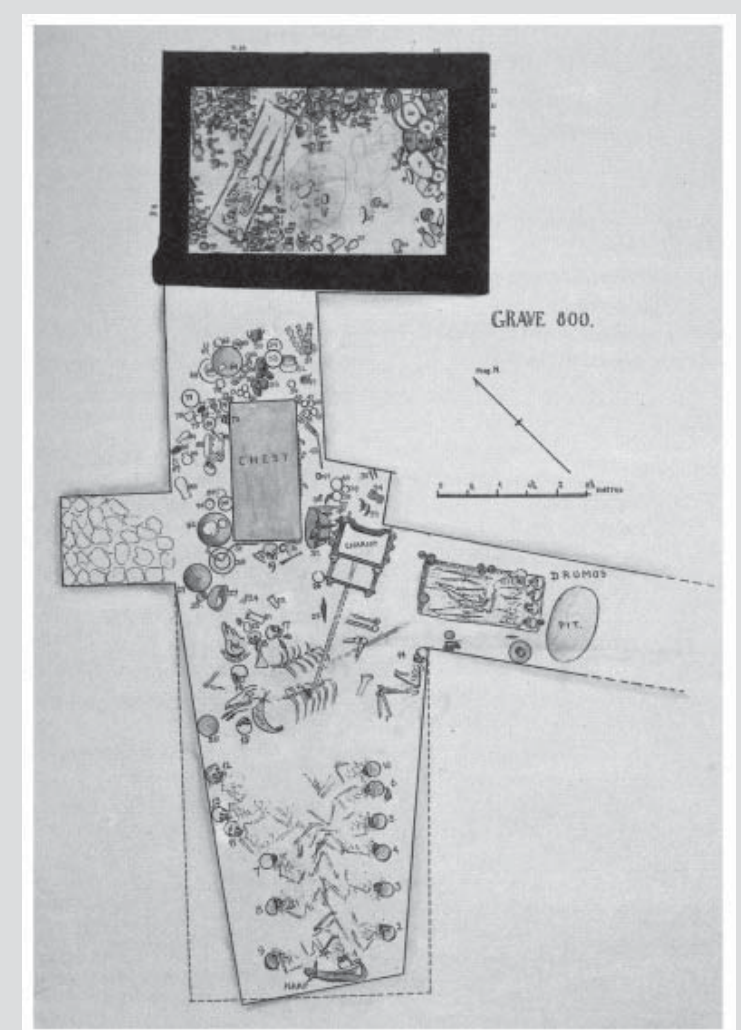

08. CHARLES LEONARD WOOLLEY. PLÀNOL DE LA TOMBA DE LA REINA PU-ABUM (O PUABI) (PG8OO), DEL CEMENTIRI REIAL
D'UR. TINTA I AQUAREL-LA SOBRE TAULA. TRUSTEES OF THE D'UR. TINTA I AQUAREL.LA SOBR
BRITISH MUSEUM, LONDRES.

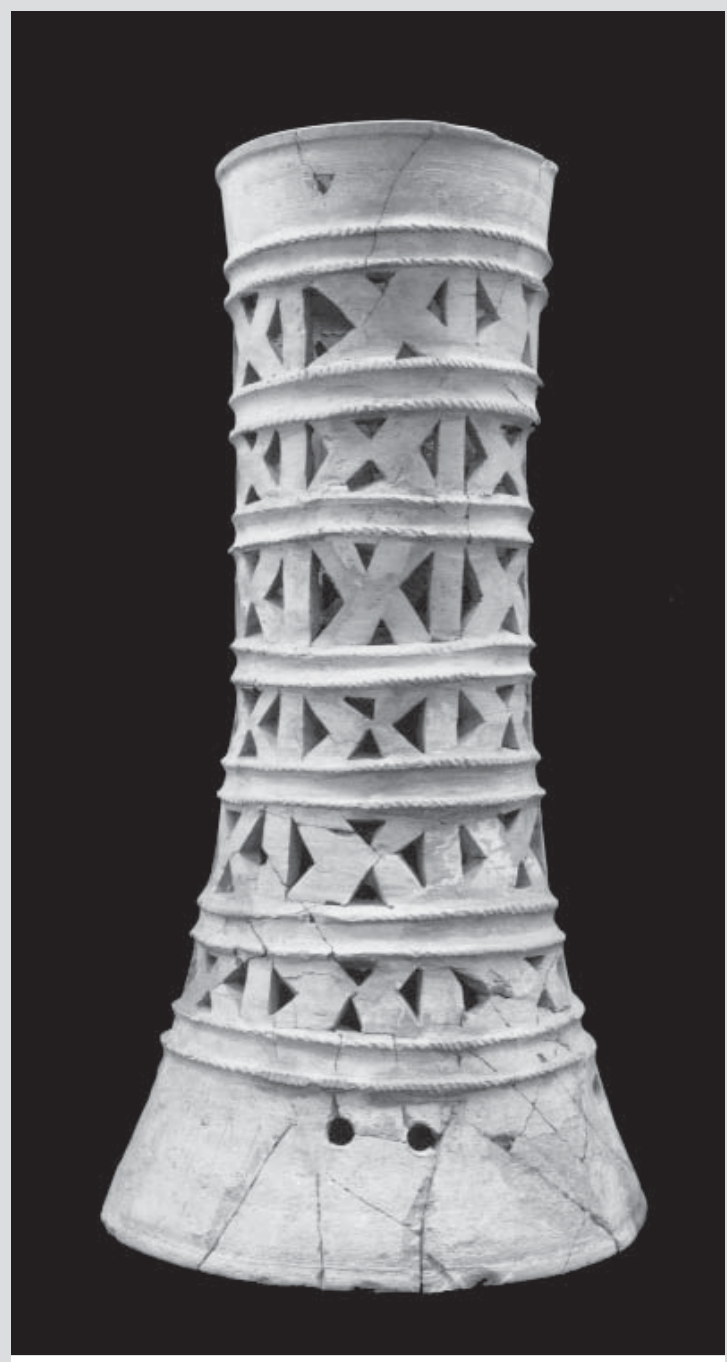

09. PEDESTAL CALAT. EXPEDICIÓ A KIŠ DEL FIELD MUSEUM I LA UNIVERSITY D'OXFORD. PERÍODE DINÀSTIC ARCAIC.
TERRACOTA, 75 Xø BOCA 26 X $\emptyset$ BASE 42 CM. FIELD MUSEUM, CHICAGO, 157060 .

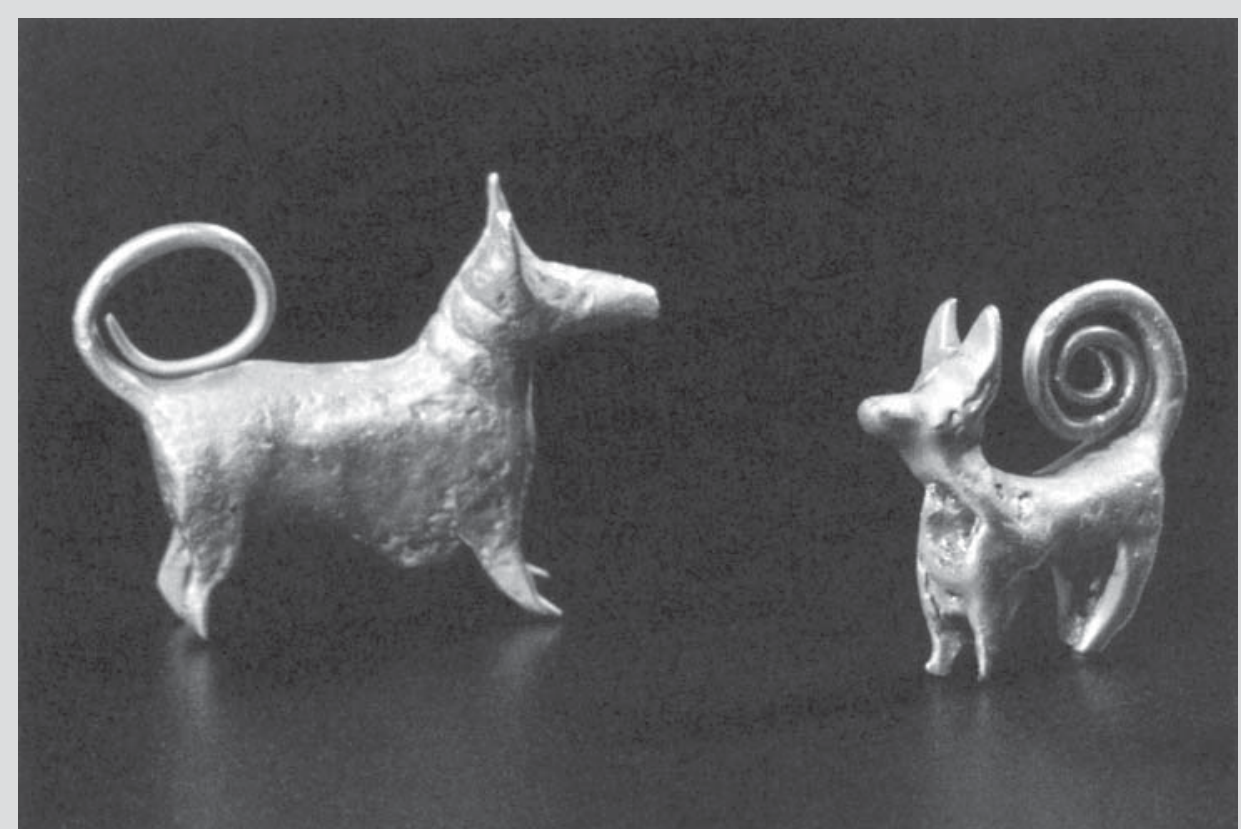

10. PEN JOLLS EN FORMA DE GOS, PROBABLEMENT ELAM (IRÀN). PERÍODE TARDÀ D’URUK YEMDET NASR. OR. 1,1 X 1,2 CM. MUSÉES ROYAUX D'ART ET D'HISTOIRE, BRUSELAS, XXX2. 
39.

Descens d'Ǐtar a l'Inframón 1. 39-62, on es narra l'entrada d'Ištar a l'inframón. Els vells costums esmentats per Ereškigal consisteixen a deixar la deessa nua en la seva entrada definitiva a l'infern, a cadascuna de les 7 portes de l'infern el porter li retira una peça de vestir.
40.

Vid. J.-F. Salles, "Rituel Mortuaire et Rituel Social à Ras Shamra / Ougarit”, in S. Campbell-A. Green (eds) The Archaeology of Death in the ANE, Oxbow Monograph 5I, I995, p. I77-I78. la idea que a Mesopotàmia els morts s'enterraven despullats, basant-se en un cert passatge del Descens d'Ištar a l'Inframón, on la deessa acaba nua abans d'entrar al regne dels morts. ${ }^{39}$ S'ha de tenir potser en compte el passatge següent del Poema de Gilgameš xii II-I6, on aquest li dóna instruccions a Enkidu de coses que no ha de fer quan sigui a l'Infern, són interessants aquestes línies que segurament es refereixen a les pràctiques i preparacions que es duien a terme amb els cossos que havien de ser enterrats:

\author{
Si [baixes] a l'Infern, \\ [segueix] els meus consells: \\ no et vesteixis amb roba neta, \\ et prendrien per un foraster. \\ No t'ungeixis amb l'oli preciós de la gerra, \\ t'envoltarien en (sentir) la seva olor.
}

\subsection{La tomba com a porta d'entrada a l'inframón}

Com hem vist més amunt en alguns texts literaris, sabem que els antics sumeris i accadis imaginaven que el món dels morts es trobava sota terra, i una de les maneres d'accedir-hi era a través de la tomba. Les troballes arqueològiques han confirmat, en alguna ocasió aquesta creença. En algunes tombes d'Ugarit es troba un forat al peu d'un dels murs, que ressegueix una mena de túnel, que dóna a una altra cavitat, o bé no dóna enlloc, i del qual se'n desconeix la finalitat o utilitat. J.-F. Salles opina que potser seria una via per a que els morts "surtin" de la tomba per participar de la vida dels vius.

En altres tombes, encara, hi ha cambres annexes, J.-F. Salles proposa que a la sala principal s'hi estarien els vius que venen a fer el ritual, i se suposa que els Refaim (els esperits dels avantpassats morts, i potser divinitzats) s'estarien a la cambra annexa, més petita. ${ }^{40}$

\section{CONCLUSIONS}

Sembla que els habitants del Pròxim Orient Antic, tant els sumeris com els accadis, i en general tots els pobles que parlaven llengües semítiques, tenien la creença que l'existència al més enllà seria una continuació de la vida a la terra, però en unes altres condicions, més extremes i dramàtiques.

Aquest lloc es trobaria a sota de la terra on hi són els vius, això és, l'inframón o infern. L'inframón és imaginat com un lloc que es troba, doncs, sota terra i on hi viuen els déus infernals, alguns dimonis i els morts. Aquest lloc és imaginat com un espai grain, més aviat trist i hostil. Aquesta visió, que percebem a partir d'alguns textos literaris, és la que haurien tingut els habitants de Mesopotàmia i la zona de Síria fins al Mediterrani, des de l'època sumèria fins l'època neo-assíria i neobabilònica.

Al món dels morts s'hi pot anar de dues maneres, una és, evidentment, quan es mor, normalment a través de la tomba; l'altra és estant encara viu, a través de qualsevol de les diverses entrades cap a l'inframón. Això sí, una vegada s'entrava a l'inframón, ja no se'n podia sortir, és un lloc del qual no se'n pot tornar, una vegada s'hi ha entrat, tal i com diuen els textos literaris.

També hi ha altres maneres d'entrar al món dels morts, una és per allà on es pon el sol. Una altra manera d'anar-hi és en horitzontal, travessant un desert, una muntanya i el riu Hubur. Al riu Hubur hi ha un barquer que porta els morts a l'altra banda (el seu nom és Humuttabal, "Porta'l ràpid"). Segons el mite de Dumuzi, 

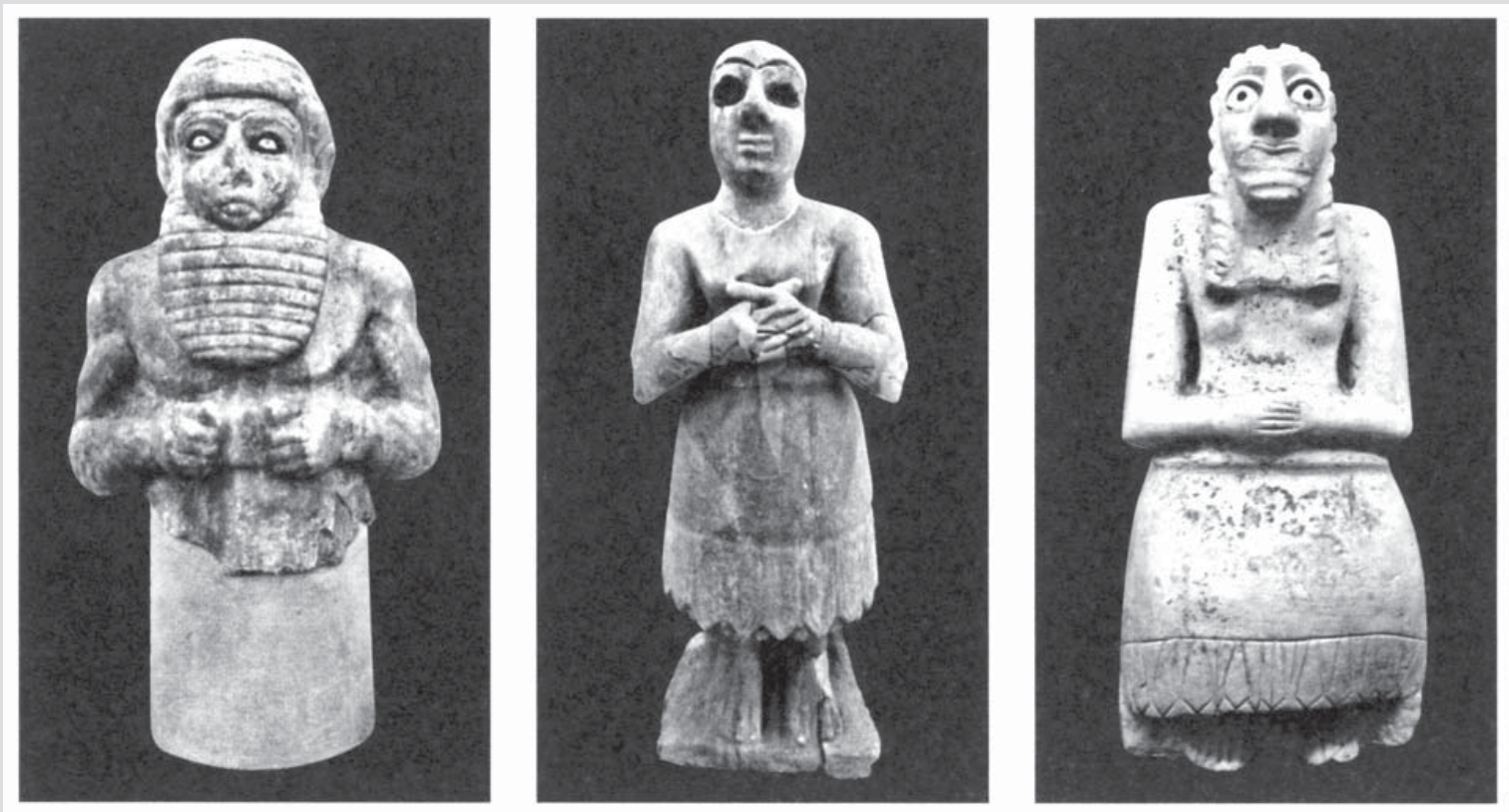

11. ESQUERRA: EFÍGIE D'HOME BARBUT. ALABASTRE, CA. 3000 A.C. NATIONAL MUSEUM OF IRAK, BAGDAD. MIG: ORADOR, III MIL.LENNI A.C. NATIONAL BAGDAD.

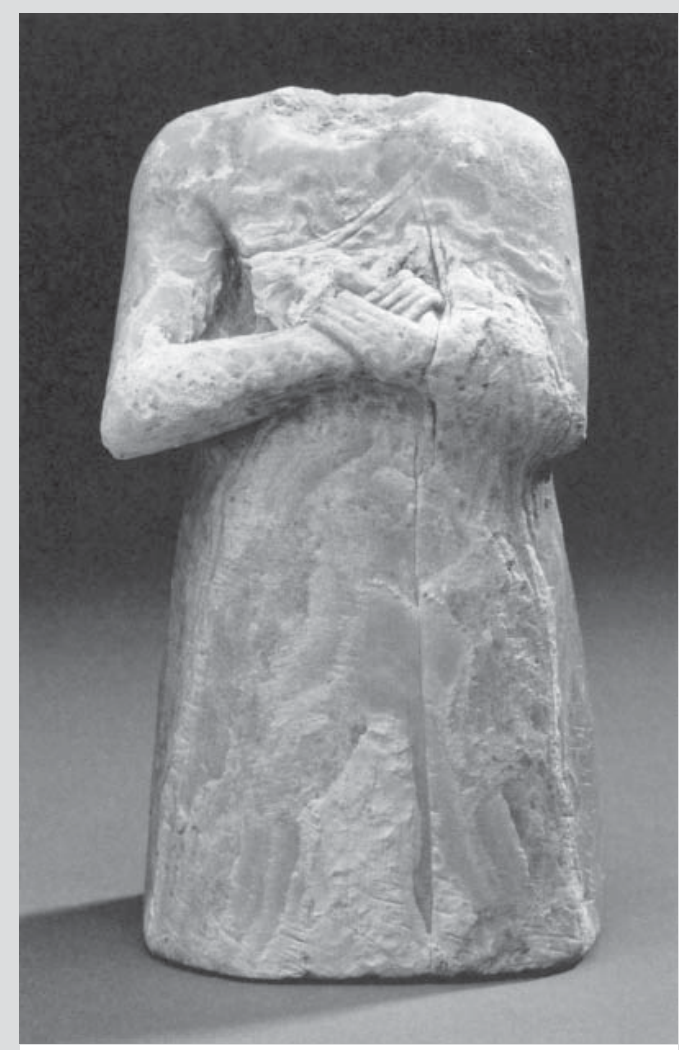

12. ESTÀTUA D'UN ORADOR. NIPPUR (IRAK), TEMPLE DE INANNA, NIVELL VIIB, SOTA DE LA CAPA INFERIOR DE LA TERRA (LOCUS 179). FINALS DEL PERÍODE DINÀSTIC ARCAIC I / "DINÀSTIC ARCAICII". ALABASTRE. 15,7 X
$8,8 \times 7,5$ CM. ROYAL ONTARIO MUSEUM, TORONTO, ROM $8,8 \times 7,5$ CM. ROYAL ONTARIO MUSEUM,
962.143 .25 ; NÚM. DE CAMP 7 N 169.

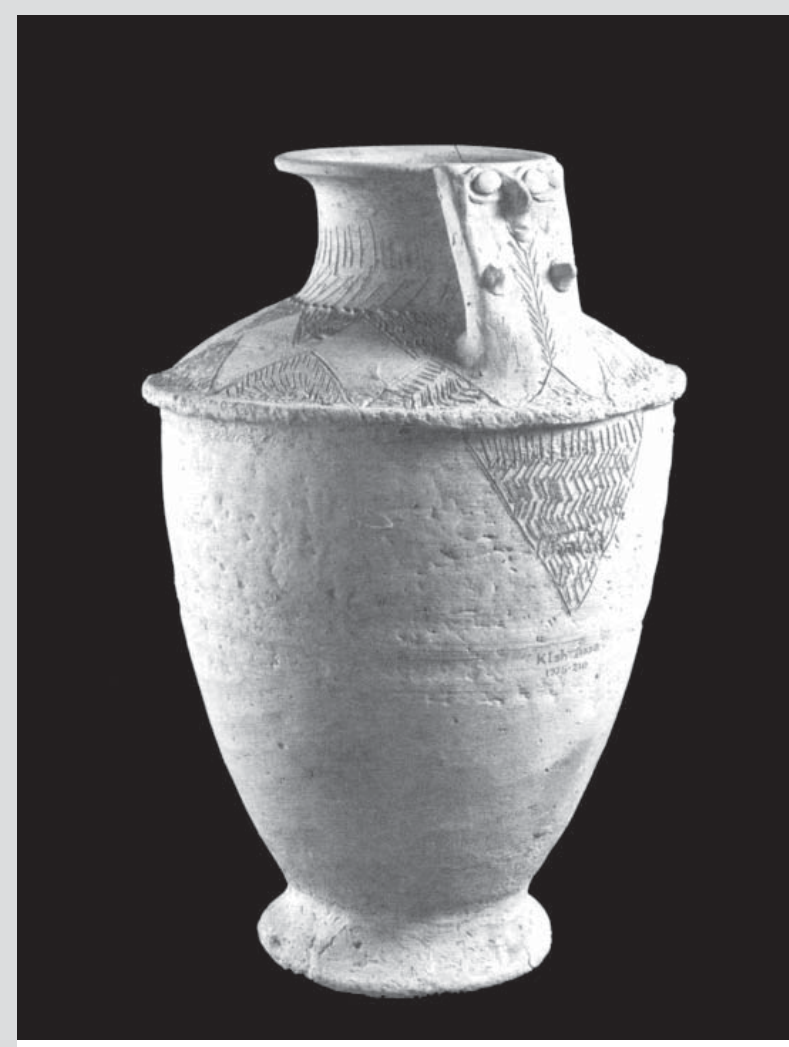

13. GERRO D'ASA VERTICAL "DE LA DEESSA-MARE". KIŠ (IRAK),

MONTÍCUL A (CEMENTIRI A). PERÍODE DINȦSTIC ARCAIC IIIB', ACADI ANTIC, CA. 2500-2250 A.C. TERRACOTA. $41 \times$ Ø 27 CM. VISITORS OF N 1925.210. 
l'entrada al món dels morts és a l'est, entre dues muntanyes per on surt el sol cada matí. Per entrar de forma correcta a l'inframón cal que l'enterrament sigui correcte, així com tot el ritual que l'envolta.

Sembla que hi ha un procés abans de l'entrada definitiva del que acaba d'arribar al món dels morts. Sembla que es decideix el lloc on ha d'anar, indicat per la seva posició de la persona mentre era viva, i no sembla que tingui res a veure amb qüestions morals.

Des d'un punt de vista físic, l'inframón se l'anomena, entre altres maneres, urugal, en sumeri, que vol dir Gran Ciutat. Segons algunes descripcions que trobem en alguns textos, més que una ciutat seria un lloc semblant a un temple o un complex palacial o templari, amb edificis diversos, patis, etc. En aquesta ciutat hi viurien els morts, i també les divinitats infernals, Ereškigal i Nergal, que serien els reis de l'inframón, juntament amb tota una cort de sers divins, a la manera de les corts terrenals.

Des d'un punt de vista arqueològic podem dir que al Pròxim Orient Antic la pràctica funerària principal era l'enterrament, sense descartar que hi hagués hagut altres tractaments del cos, però en tot cas haurien estat minoritaris. Els enterraments tenien lloc tant fora dels llocs d'habitatge, en cementiris, com als mateixos llocs d'habitatge, normalment sota les cases. Les tombes eren accessibles i a partir de les observacions que s'han fet, queda clar que la tomba constitueix la porta d'entrada cap a l'inframón, de vegades amb canalitzacions o passadissos que s'enfonsen més cap a la terra, cosa que indicaria la via que els morts han de seguir cap a l'inframón.

\section{BIBLIOGRAFÍA}

S. ANTHONIOZ, "De la mort qui sépare à celle qui unit: le message et la formation de l'épopée de Gilgameš", in J.-M. Durand-T. Römer-J. Hutzli (eds), Les vivants et leurs morts, OBO 257 Fribourg-Göttingen 2012.

H. BAKER, "Neo-Babylonian Burials Revisited", in S. Campbell-A. Green (eds) The Archaeology of Death in the ANE, Oxbow Monograph 5I, I995

E. BAXEVANI, "The Complex Nomads: Death and Social Stratification in EB IV Southern Levant", in S. Campbell-A. Green (eds) The Archaeology of Death in the ANE, Oxbow Monograph 5I, I995.

Enuma elis, L. FELIU-A. MILLET (introducció, traducció i notes), El Poema Babilònic de la Creació i altres cosmogonies menors, Barcelona 2004 .

W. HOROWITZ, Mesopotamian Cosmic Geography, Winona Lake Indiana, I998.

SAA 3 = A. LIVINGSTONE, Court Poetry and Literary Miscellanea. State Archives of Assyria III, Helsinki University Press I989.

D. ILAN, "Mortuary Practices at Tel Dan in the Middle Bronze Age: a Reflection of Canaanaite Society and Ideology", in S. Campbell-A. Green (eds) The Archaeology of Death in the ANE, Oxbow Monograph 5I, I995.

Poema de Gilgameš, L. FELIU-A. MILLET (introducció, traducció i notes), El Poema de Gilgamesh segons els manuscrits en llengua accàdia dels mil·lennis II i I aC, Barcelona 2007.

J.-F. SALLES, "Rituel Mortuaire et Rituel Social à Ras Shamra / Ougarit", in S. Campbell-A. Green (eds) The Archaeology of Death in the ANE, Oxbow Monograph 5I, I995.

W.R. SLADEK, Inanna's Descent to the Netheworld, The Johns Hopkins University, Ph.D., I974. University Microfilm, A XEROX Company, Ann Arbor Michigan.

UET 6/I = G.J. GADD-S.N. KRAMER, Literary and Religious Texts. Ur Excavation Texts VI, I963.

N. ZIEGLER, Le harem de Zimri-Lim, Florilegium Marianum IV, Paris 2003. 